\title{
Irradiation Test Plan for the ATR National Scientific User Facility - University of Wisconsin Pilot Project
}

Heather J. MacLean

Kumar Sridharan

Timothy A. Hyde

June 2008

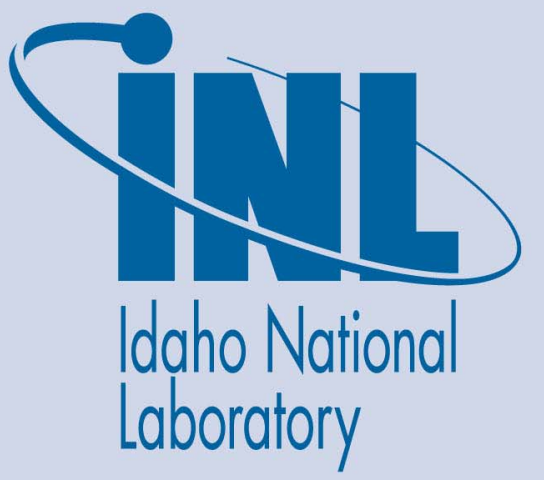

The INL is a U.S. Department of Energy National Laboratory operated by Battelle Energy Alliance 


\section{Irradiation Test Plan for the ATR National Scientific User Facility - University of Wisconsin Pilot Project}

Heather J. MacLean

Kumar Sridharan

Timothy A. Hyde

June 2008

\section{Idaho National Laboratory \\ Idaho Falls, Idaho 83415}

http://www.inl.gov

Prepared for the

U.S. Department of Energy

Office of Nuclear Energy

Under DOE Idaho Operations Office

Contract DE-AC07-05ID14517 


\section{DISCLAIMER}

This information was prepared as an account of work sponsored by an agency of the U.S. Government. Neither the U.S. Government nor any agency thereof, nor any of their employees, makes any warranty, expressed or implied, or assumes any legal liability or responsibility for the accuracy, completeness, or usefulness, of any information, apparatus, product, or process disclosed, or represents that its use would not infringe privately owned rights. References herein to any specific commercial product, process, or service by trade name, trade mark, manufacturer, or otherwise, does not necessarily constitute or imply its endorsement, recommendation, or favoring by the U.S. Government or any agency thereof. The views and opinions of authors expressed herein do not necessarily state or reflect those of the U.S. Government or any agency thereof. 



\section{CONTENTS}

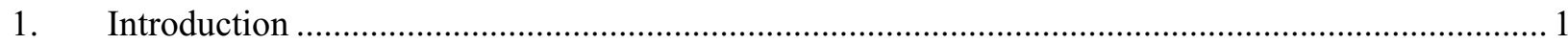

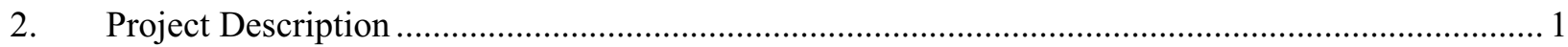

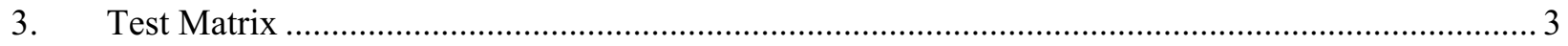

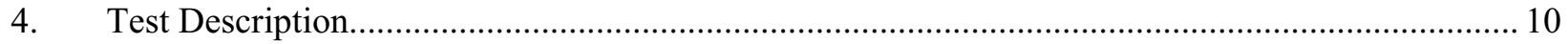

4.1 Material Specimens ..............................................................Error! Bookmark not defined.

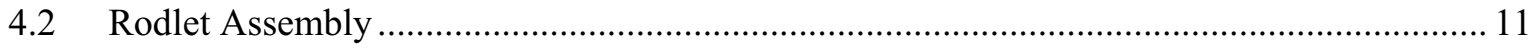

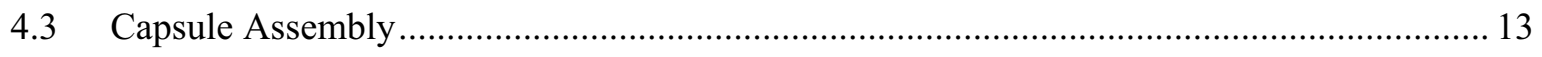

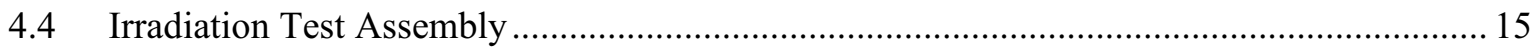

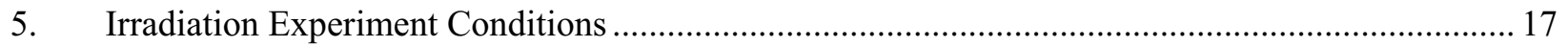

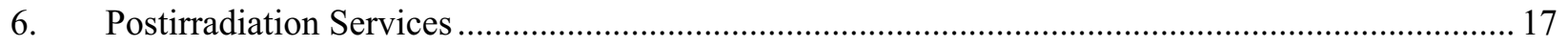

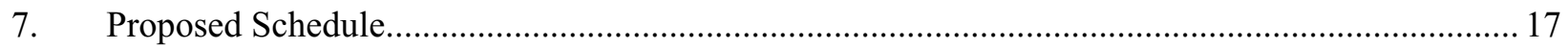

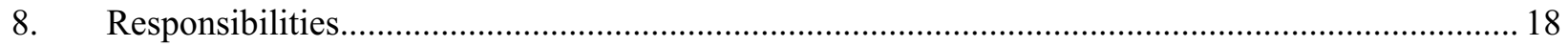




\section{FIGURES}

Figure 1. TEM Specimen Schematic

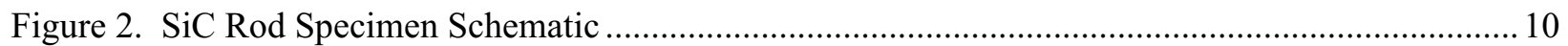

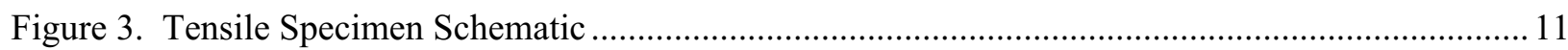

Figure 4. Radial dimensions of rodlet and capsule assemblies for the UW materials irradiation TEM specimens.

Figure 5. Radial dimensions of rodlet and capsule assemblies for the UW materials irradiationtensile specimens

Figure 6. Example rodlet axial configuration for the UW irradiation experiment.................................. 13

Figure 7. Capsule Assembly Schematic with Proposed Rodlet Loading ............................................... 15

Figure 8. UW Experiment Irradiation Test Assembly for ATR East Flux Trap Positions

\section{TABLES}

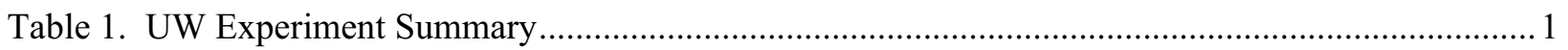

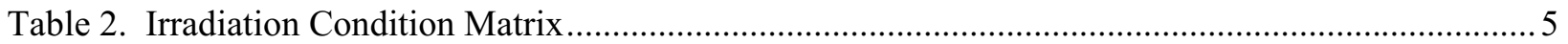

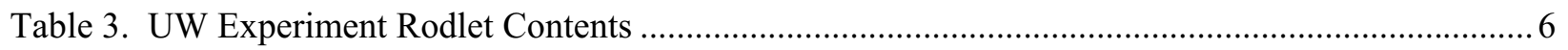

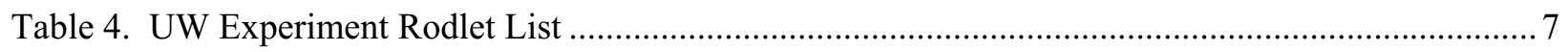

Table 5. UW Experiment Material Composition $\dagger$ - Metallic Alloys ....................................................... 8

Table 6. UW Experiment Material Composition $\dagger$ - Ceramics ............................................................... 9

Table 7. UW Experiment Material Composition $\uparrow-$ Refractory Alloys and Silver .................................. 9

Table 8. UW Experiment Material Composition $\uparrow-$ Amorphous Metals Fabricated at UW ...................... 9

Table 9. UW Experiment Material Composition $\dagger-\mathrm{MgO}-\mathrm{ZrO}_{2}$ Fabricated at UW ................................. 9

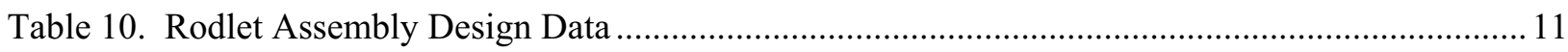

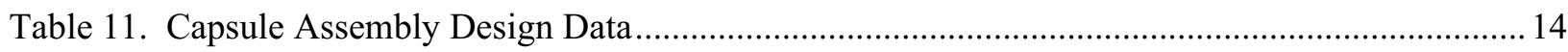

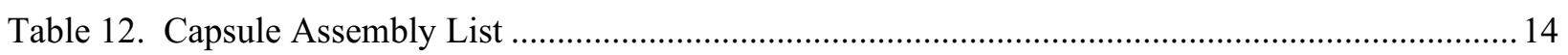

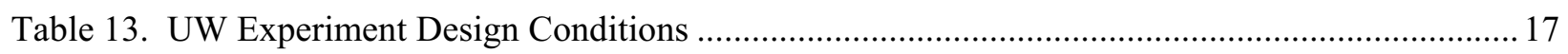




\section{Irradiation Test Plan for the ATR National Scientific User Facility - University of Wisconsin Pilot Project}

\section{INTRODUCTION}

The performance of advanced nuclear systems critically relies on the performance of the materials used for cladding, duct, and other structural components. In many proposed advanced systems, the reactor design pushes the temperature and the total radiation dose higher than typically seen in a light water reactor. Understanding the stability of these materials under radiation is critical. There are a large number of materials or material systems that have been developed for greater high temperature or high dose performance for which little or no information on radiation response exists. The goal of this experiment is to provide initial data on the radiation response of these materials.

The objective of the UW experiment is to irradiate materials of interest for advanced reactor applications at a variety of temperatures (nominally $300^{\circ} \mathrm{C}, 400^{\circ} \mathrm{C}, 500^{\circ} \mathrm{C}$, and $700^{\circ} \mathrm{C}$ ) and total dose accumulations (nominally $3 \mathrm{dpa}$ and $6 \mathrm{dpa}$ ). Insertion of this irradiation test is proposed for September 2008 (ATR Cycle 143A).

Table 1. UW Experiment Summary

\begin{tabular}{|c|c|c|c|}
\hline $\begin{array}{c}\text { UW Experiment } \\
\text { Designation Capsule ID }\end{array}$ & Material & ATR Insertion & Target Dose \\
\hline \hline UW-0 & N/A & September 2008 & N/A \\
\hline UW-1, UW-2 & Metals, Ceramics & September 2008 & $3 \mathrm{dpa}$ \\
\hline UW-3 & Metals, Ceramics & September 2008 & $6 \mathrm{dpa}$ \\
\hline
\end{tabular}

\section{PROJECT DESCRIPTION}

The Idaho National Laboratory, through the Department of Energy Idaho Operations Office, has been assigned the responsibility of irradiating experiments for the Advanced Test Reactor (ATR) National Scientific User Facility (NSUF). Irradiation of the ATR NSUF University of Wisconsin (UW) pilot project will be done in the East Flux Trap (EFT) of the ATR.

In order to accomplish this, INL will be responsible for:

- fabricating cadmium shrouded EFT baskets to house the capsules in the Irradiation Housing Assembly (IHA) during irradiation;

- performing neutronic analysis of the aggregate capsules;

- performing thermal hydraulic analysis of the experiment assembly;

- receiving material specimens from UW;

- encapsulating material specimens into sealed rodlets; 
- fabricating an ASME Section III, Class 1 pressure vessel capsule;

- encapsulating rodlets into secondary ASME pressure vessel capsule;

- preparing the Experiment Safety Assurance Package (ESAP) and obtaining approval of the package, allowing reactor insertion of the experiment;

- transporting the experiment capsules to RTC;

- receiving the capsules and placement into cadmium shrouded baskets;

- inserting the assemblies in the ATR and irradiation of the capsules to the specified fluence;

- experiment handling and basket change outs during reactor outages;

- storing as necessary in the ATR canal for cool down;

- $\quad$ shipping the irradiated capsules to HFEF located at MFC;

- collaboratively performing postirradiation examination (PIE) with UW researchers; and

- $\quad$ shipping select samples to UW for analysis.

INL will provide project management and project engineering of all activities from the beginning of experiment planning through PIE.

The experiment fabrication and irradiation will be a coordinated effort between INL personnel located at the Research and Education Campus (REC), Materials and Fuels Complex (MFC), and the Reactor Technology Complex (RTC). Fabrication of the rodlets, capsules and cadmium baskets will be performed at MFC and INL Research Complex (IRC).

INL will fabricate the capsules suitable for ATR irradiation. The capsules will be fabricated in the form of a drop-in containment vessel and will be fabricated and assembled in accordance with reference design specifications under ASME Section III, Class 1.

INL will fabricate the cadmium shrouded baskets to house the capsules in the EFT during irradiation. These baskets will be designed such that adequate fluence to meet test conditions is ensured, that there is adequate coolant circulation to prevent temperature distortions or mechanical effects, and that there is adequate mechanical support to secure the test capsule throughout the processes of reactor insertion, irradiation, and removal from the reactor. These baskets will be fabricated to mate precisely with all exterior dimensions of the test capsules and with all interior dimensions of the ATR EFT IHA as currently configured.

INL will perform all neutronic and thermal analyses, and will prepare the Experiment Safety Assurance Package required for ATR experiment insertion. The ESAP will be reviewed by Experiment Engineering, Nuclear Safety, and will be approved by the Safety Operations Review Committee (SORC).

All arrangements will be made to package, load, and transport the capsules for delivery to the ATR for irradiation. Upon receipt, the capsules will be placed in cadmium shrouded baskets and placed in their respective positions in the EFT IHA in preparation for irradiation.

The capsules will be removed from the ATR core during regularly scheduled ATR outages as needed to replace the cadmium baskets. Upon achieving the specified fluence, the capsules will be removed from the ATR and stored in the ATR canal for a minimum of 30 days for cool down. 
The capsule assembly and aluminum sheathed cadmium segment of the basket assembly will be shipped to the Hot Fuels Examination Facility (HFEF) at MFC for postirradiation examinations (PIE). Shipment from the RTC to HFEF will be made using the GE Model 2000 shipping cask or other authorized shipping container. PIE activities will be performed at MFC in HFEF, Analytical Laboratory, and Electron Microscopy Laboratory, and will include mechanical and microhardness testing, X-ray diffraction, and scanning and transmission electron microscopy.

\section{TEST MATRIX}

The first set of materials to be investigated in the UW experiment are advanced ferritic-martensitic steels, specifically HT9, T91, HCM12A (T122), NF616 (T92), ODS, and 9Cr and 12Cr model alloys. The body-centered cubic (BCC) structure of the alloys and negligibly low Ni-content make these alloys generally stable to swelling under radiation. HCM12A is a $12 \mathrm{Cr}$ alloy and can be considered as an advanced version of HT9, the $12 \mathrm{Cr}$ steel used extensively for cladding and duct in the U.S. Fast Breeder program. NF616 is a $9 \mathrm{Cr}$ steel and can be considered an advancement beyond T91, an alloy that has received considerable attention in the U.S. fusion materials development program. Oxide dispersion strengthened (ODS) steels have been developed to provide higher temperature strength and radiation damage resistance through the incorporation of nanometer sized oxide clusters that provide strength and trapping sites for radiation-induced defects. There are open questions about the high temperature stability under radiation of the nanoclusters. The $9 \mathrm{Cr}$ and $12 \mathrm{Cr}$ model alloys have the same base composition (Fe and $\mathrm{Cr}$ ) as NF616 and HCM12A and can provide valuable data for validating advanced modeling. These alloys are all currently being investigated by ion irradiation as part of the NERI consortia project on advanced cladding being performed at the University of Wisconsin, University of Michigan, Pennsylvania State University, the University of California-Berkeley, and the University of California-Santa Barbara. The neutron irradiation data will provide an excellent compliment to the data being generated using ion irradiation studies.

Austenitic alloys inherently have higher allowable operating temperatures than ferritic-martensitic alloys and were the original alloys of choice for fast reactor cladding and ducts. However, austenitic alloys were limited by their void swelling behavior. Towards the end of the U.S. fast breeder materials development program, a nano-precipitation-strengthened austenitic steel (known as HT-UPS) was developed with the goal of using nanometer-sized carbides to trap radiation-induced defects. The ability to trap defects is anticipated to both increase strength and limit void swelling (similar to the effect of the nanometer-sized oxide clusters in the ferritic-martensitic ODS steels described above). Because the breeder materials program ended before these HT-UPS alloys could be tested, there is little known about the response of this alloy to radiation. Two other austenitic steels that have been developed for higher strength by fossil generation programs are also of interest for fast reactor structural materials, NF709 and Super 304. HTUPS and NF709 are also currently being investigated as part of the NERI consortia project on advanced cladding being performed at the University of Wisconsin, University of Michigan, Pennsylvania State University, the University of California-Berkeley, and the University of California-Santa Barbara.

In recent years, novel materials and techniques have been developed that might lead to more radiationresilient materials. In most cases, not data on radiation response exists. Each will be explained in the following bullets:

- Amorphous metals (also known as bulk metallic glass): Over the last decade, the ability to produce bulk amorphous metals has been established. These systems have been proposed as 
coating materials to limit oxidation effects and are of interest to Westinghouse. No known experiments on the response of metallic glasses to irradiation exist.

- Grain Boundary Engineering (GBE): The ability to optimize the types of grain boundaries within a grain boundary network has been shown to improve the creep, stress corrosion cracking, and oxidation performance of certain alloys. Recently, grain boundary engineering was performed on alloy $800 \mathrm{H}$, one of the five alloys approved in section $\mathrm{NH}$ of the ASME code. This treatment greatly reduced the spallation of the oxide that forms when exposed to supercritical water. More importantly, in mechanical tests performed following radiation exposure in the HFIR reactor, the post radiation ductility of the grain boundary engineered $800 \mathrm{H}$ was significantly better than the non-treated $800 \mathrm{H}$. No microstructural observations have been made of the HFIR samples. Because, GBE involves plastic deformation, most studies involving this technique have been performed using austenitic alloys. One of the objectives of this study will be to subject ferritic-martensitic steels to GBE treatment and then investigate the radiation response.

- $\mathrm{MgO}-\mathrm{ZrO}_{2}$ binary ceramic system: $\mathrm{The} \mathrm{MgO}-\mathrm{ZrO}_{2}$ system has been proposed as an inert matrix for light water reactor transmutation fuels. The zirconia provides corrosion resistance while the magnesia provides good thermal conductivity. No radiation response data exists on this binary ceramics, particularly at the interfaces between the two phases. $\mathrm{MgO}-\mathrm{ZrO}_{2}$ is also currently being investigated as part of a NERI project being performed at the University of Wisconsin.

- Refractory alloys and silver: For very high temperature applications, refractory metals have been proposed as structural components. In most cases, radiation response data on refractory alloys is extremely limited. Three materials are proposed in this category for this study: W, Ag, and Mo-ODS. Westinghouse has a strong interest in the radiation response of tungsten and silver. The Mo-ODS has nanometer-sized lanthanum oxide particles throughout the matrix, similar to the ferritic-martensitic ODS. There is considerable interest in determining if the oxide particles improve the radiation response of molybdenum.

The goal of the UW irradiation experiment is to irradiate the materials described above at four different temperatures and to two different doses. The nominal desired irradiation temperatures are $300^{\circ} \mathrm{C}, 400^{\circ} \mathrm{C}$, $500^{\circ} \mathrm{C}$ and $700^{\circ} \mathrm{C}$. The nominal desired dose accumulations are $3 \mathrm{dpa}$ and $6 \mathrm{dpa}$. The proposed test matrix including the materials to be irradiated at each temperature and dose conditions is listed in Table 2 . Three sample geometries will be included in the UW irradiation experiment: TEM, rod, and tensile specimens. A listing of the materials specimens in each rodlet, and the rodlet length is shown in Table 3. A summary list of rodlets is included in Table 4. 
Table 2. Irradiation Condition Matrix

\begin{tabular}{|c|c|c|c|c|c|c|c|c|c|}
\hline \multirow{2}{*}{$\begin{array}{l}\text { Material } \\
\text { Category }\end{array}$} & \multirow{2}{*}{$\overbrace{\text { Material ID }}^{\text {Temperature }}$} & \multicolumn{2}{|c|}{$300^{\circ} \mathrm{C}$} & \multicolumn{2}{|c|}{$400^{\circ} \mathrm{C}$} & \multicolumn{2}{|c|}{$500^{\circ} \mathrm{C}$} & \multicolumn{2}{|c|}{$700^{\circ} \mathrm{C}$} \\
\hline & & low & high & low & high & low & high & low & high \\
\hline \multirow{12}{*}{$\begin{array}{l}\text { Ferritic- } \\
\text { Martensitic } \\
\text { Steels }\end{array}$} & HT-9 EBR-II $^{\dagger}$ & $\mathrm{t}$ & $\mathrm{t}$ & 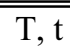 & 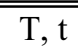 & 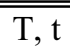 & 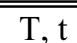 & & \\
\hline & HT-9 LANL $^{\dagger}$ & $\mathrm{t}$ & $\mathrm{t}$ & $\mathrm{T}, \mathrm{t}$ & $\mathrm{T}, \mathrm{t}$ & $\mathrm{T}, \mathrm{t}$ & $\mathrm{T}, \mathrm{t}$ & & \\
\hline & HT-9 ORNL & $\mathrm{t}$ & $\mathrm{t}$ & $\mathrm{T}, \mathrm{t}$ & $\mathrm{T}, \mathrm{t}$ & $\mathrm{T}, \mathrm{t}$ & $\mathrm{T}, \mathrm{t}$ & & \\
\hline & T91 & & & $\mathrm{T}$ & $\mathrm{T}$ & $\mathrm{T}$ & $\mathrm{T}$ & & \\
\hline & HCM12A & & & $\mathrm{T}$ & $\mathrm{T}$ & $\mathrm{T}$ & $\mathrm{T}$ & & \\
\hline & HCM12A-TMP & & & $\mathrm{T}$ & $\mathrm{T}$ & $\mathrm{T}$ & $\mathrm{T}$ & & \\
\hline & NF616 & $\mathrm{t}$ & $\mathrm{t}$ & $\mathrm{T}, \mathrm{t}$ & $\mathrm{T}, \mathrm{t}$ & $\mathrm{T}, \mathrm{t}$ & $\mathrm{T}, \mathrm{t}$ & & \\
\hline & $9 \mathrm{Cr}$ ODS & & & $\mathrm{T}$ & $\mathrm{T}$ & $\mathrm{T}$ & $\mathrm{T}$ & $\mathrm{T}$ & $\mathrm{T}$ \\
\hline & $800 \mathrm{H}^{\dagger}$ & & & $\mathrm{T}$ & $\mathrm{T}, \mathrm{t}$ & $\mathrm{T}, \mathrm{t}$ & $\mathrm{T}, \mathrm{t}$ & & \\
\hline & $800 \mathrm{H}-\mathrm{TMP}^{+}$ & & & $\mathrm{T}$ & $\mathrm{T}, \mathrm{t}$ & $\mathrm{T}, \mathrm{t}$ & $\mathrm{T}, \mathrm{t}$ & & \\
\hline & 9Cr Model Alloy & $\mathrm{T}$ & $\mathrm{T}$ & $\mathrm{T}$ & $\mathrm{T}$ & $\mathrm{T}$ & $\mathrm{T}$ & & \\
\hline & 12Cr Model Alloy & $\mathrm{T}$ & $\mathrm{T}$ & $\mathrm{T}$ & $\mathrm{T}$ & $\mathrm{T}$ & $\mathrm{T}$ & & \\
\hline \multirow{4}{*}{$\begin{array}{l}\text { Austenitic } \\
\text { Steels }\end{array}$} & HT-UPS-AX-6 & & & $\mathrm{T}, \mathrm{t}$ & $\mathrm{T}, \mathrm{t}$ & $\mathrm{T}, \mathrm{t}$ & $\mathrm{T}, \mathrm{t}$ & $\mathrm{T}, \mathrm{t}$ & $\mathrm{T}, \mathrm{t}$ \\
\hline & D9 & & & $\mathrm{T}$ & $\mathrm{T}$ & $\mathrm{T}$ & $\mathrm{T}$ & & \\
\hline & NF709 & & & $\mathrm{T}, \mathrm{t}$ & $\mathrm{T}, \mathrm{t}$ & $\mathrm{T}, \mathrm{t}$ & $\mathrm{T}, \mathrm{t}$ & $\mathrm{T}, \mathrm{t}$ & $\mathrm{T}, \mathrm{t}$ \\
\hline & Super 304H & & & $\mathrm{T}$ & $\mathrm{T}$ & $\mathrm{T}$ & $\mathrm{T}$ & $\mathrm{T}$ & $\mathrm{T}$ \\
\hline \multirow{2}{*}{ Ceramics } & $\mathrm{MgO}-\mathrm{ZrO}_{2}$ & & & & & & & $\mathrm{~T}$ & $\mathrm{~T}$ \\
\hline & $\mathrm{SiC}$ & & & & & & & $\mathrm{R}$ & \\
\hline \multirow{3}{*}{$\begin{array}{l}\text { Refractory } \\
\text { Alloys and } \\
\text { Silver }\end{array}$} & Mo-ODS & & & $\mathrm{T}$ & $\mathrm{T}$ & $\mathrm{T}$ & $\mathrm{T}$ & $\mathrm{T}$ & $\mathrm{T}$ \\
\hline & $\mathrm{W}$ & & & $\mathrm{T}$ & $\mathrm{T}$ & $\mathrm{T}$ & $\mathrm{T}$ & $\mathrm{T}$ & $\mathrm{T}$ \\
\hline & $\mathrm{Ag}$ & & & $\mathrm{T}$ & $\mathrm{T}$ & $\mathrm{T}$ & $\mathrm{T}$ & $\mathrm{T}$ & $\mathrm{T}$ \\
\hline \multirow{5}{*}{$\begin{array}{l}\text { Amorphous } \\
\text { Metals }\end{array}$} & Amorphous Fe 1 & $\mathrm{~T}$ & $\mathrm{~T}$ & & & $\mathrm{~T}$ & $\mathrm{~T}$ & & \\
\hline & Amorphous Fe 2 & $\mathrm{~T}$ & $\mathrm{~T}$ & & & $\mathrm{~T}$ & $\mathrm{~T}$ & & \\
\hline & Amorphous Fe 3 & $\mathrm{~T}$ & $\mathrm{~T}$ & & & $\mathrm{~T}$ & $\mathrm{~T}$ & & \\
\hline & Amorphous $\mathrm{Fe} 4$ & $\mathrm{~T}$ & $\mathrm{~T}$ & & & $\mathrm{~T}$ & $\mathrm{~T}$ & & \\
\hline & Amorphous Fe 5 & $\mathrm{~T}$ & $\mathrm{~T}$ & & & $\mathrm{~T}$ & $\mathrm{~T}$ & & \\
\hline
\end{tabular}

$\mathrm{T}=$ TEM specimen (3-mm diameter $\times 0.2$-mm height) $(4$ TEM specimens per material and condition)

$\mathrm{t}=$ tensile specimen (16-mm length $\times 4$-mm width) (2 tensile specimens per material and condition)

$\mathrm{R}=$ rod specimen $(3-\mathrm{mm}$ diameter $\times 12.7-\mathrm{mm}$ height $)$

$\dagger$ only 1 tensile specimen each for HT-9 EBR-II and HT-9 LANL per irradiation condition

$\$$ only 1 tensile specimen each for $800 \mathrm{H}$ and $800 \mathrm{H}$-TMP per irradiation condition 
Table 3. UW Experiment Rodlet Contents

\begin{tabular}{|c|c|c|c|}
\hline \multirow{2}{*}{$\begin{array}{l}\text { Rodlet } \\
\text { ID }\end{array}$} & \multicolumn{2}{|r|}{ Rodlet Contents } & \multirow{2}{*}{$\begin{array}{l}\text { Rodlet } \\
\text { Length } \\
\text { (in.) }\end{array}$} \\
\hline & $\begin{array}{l}\text { Specimen } \\
\text { Type }\end{array}$ & Material & \\
\hline \multirow[t]{2}{*}{$300 \mathrm{LO}$} & TEM & $\begin{array}{l}\text { 9Cr Model Alloy, } 12 \text { Cr Model Alloy, Amorphous Fe 1, Amorphous Fe 2, } \\
\text { Amorphous Fe 3, Amorphous Fe 4, Amorphous Fe } 5\end{array}$ & \multirow[t]{2}{*}{4.4} \\
\hline & Tensile & HT-9 EBR-II, HT-9 LANL, HT-9 ORNL, NF616 & \\
\hline \multirow[t]{2}{*}{$300 \mathrm{HI}$} & TEM & $\begin{array}{l}\text { 9Cr Model Alloy, } 12 \text { Cr Model Alloy, Amorphous Fe 1, Amorphous Fe 2, } \\
\text { Amorphous Fe 3, Amorphous Fe 4, Amorphous Fe } 5\end{array}$ & \multirow[t]{2}{*}{3.9} \\
\hline & Tensile & HT-9 EBR-II, HT-9 LANL, HT-9 ORNL, NF616 & \\
\hline $400 \mathrm{LO}$ A & TEM & $\begin{array}{l}\text { HT-9 EBR-II, HT-9 LANL, HT-9 ORNL, T91, HCM12A, HCM12A-TMP, } \\
\text { NF616, 9Cr ODS, 800H, 800H-TMP, 9Cr Model Alloy, } 12 \text { Cr Model Alloy, } \\
\text { HT-UPS-AX-6, D9, NF709, Super 304H, Mo-ODS, W, Ag }\end{array}$ & 2.4 \\
\hline 400 LO B & Tensile & HT-9 EBR-II, HT-9 LANL, HT-9 ORNL, NF616, HT-UPS-AX-6, NF709 & 5.0 \\
\hline $400 \mathrm{HI} \mathrm{A}$ & TEM & $\begin{array}{l}\text { HT-9 EBR-II, HT-9 LANL, HT-9 ORNL, T91, HCM12A, HCM12A-TMP, } \\
\text { NF616, 9Cr ODS, 800H, 800H-TMP, 9Cr Model Alloy, } 12 \text { Cr Model Alloy, } \\
\text { HT-UPS-AX-6, D9, NF709, Super 304H, Mo-ODS, W, Ag }\end{array}$ & 2.4 \\
\hline 400 HI B & Tensile & $\begin{array}{l}\text { HT-9 EBR-II, HT-9 LANL, HT-9 ORNL, NF616, 800H, 800H-TMP, HT-UPS- } \\
\text { AX-6, NF709 }\end{array}$ & 6.3 \\
\hline $500 \mathrm{LO} A$ & TEM & $\begin{array}{l}\text { HT-9 EBR-II, HT-9 LANL, HT-9 ORNL, T91, HCM12A, HCM12A-TMP, } \\
\text { NF616, 9Cr ODS, 800H, 800H-TMP, 9Cr Model Alloy, 12Cr Model Alloy, } \\
\text { HT-UPS-AX-6, D9, NF709, Super 304H, Mo-ODS, W, Ag, Amorphous Fe 1, } \\
\text { Amorphous Fe 2, Amorphous Fe 3, Amorphous Fe 4, Amorphous Fe 5 }\end{array}$ & 3.1 \\
\hline $500 \mathrm{LO} B$ & Tensile & $\begin{array}{l}\text { HT-9 EBR-II, HT-9 LANL, HT-9 ORNL, NF616, 800H, 800H-TMP, HT-UPS- } \\
\text { AX-6, NF709 }\end{array}$ & 6.3 \\
\hline $500 \mathrm{HI} \mathrm{A}$ & TEM & $\begin{array}{l}\text { HT-9 EBR-II, HT-9 LANL, HT-9 ORNL, T91, HCM12A, HCM12A-TMP, } \\
\text { NF616, 9Cr ODS, 800H, 800H-TMP, 9Cr Model Alloy, 12Cr Model Alloy, } \\
\text { HT-UPS-AX-6, D9, NF709, Super 304H, Mo-ODS, W Goodfellow, W } \\
\text { Columbia, Ag, Amorphous Fe 1, Amorphous Fe 2, Amorphous Fe 3, } \\
\text { Amorphous Fe 4, Amorphous Fe } 5\end{array}$ & 2.6 \\
\hline $500 \mathrm{HI} \mathrm{B}$ & Tensile & $\begin{array}{l}\text { HT-9 EBR-II, HT-9 LANL, HT-9 ORNL, NF616, 800H, 800H-TMP, HT-UPS- } \\
\text { AX-6, NF709 }\end{array}$ & 6.3 \\
\hline \multirow{3}{*}{$700 \mathrm{LO}$} & TEM & 9Cr ODS, HT-UPS-AX-6, NF709, Super 304, Mg-ZrO, Mo-ODS, W, Ag & \multirow{3}{*}{3.8} \\
\hline & Rod & $\mathrm{SiC}$ & \\
\hline & Tensile & HT-UPS-AX-6, NF709 & \\
\hline \multirow{2}{*}{$700 \mathrm{HI}$} & TEM & 9Cr ODS, HT-UPS-AX-6, NF709, Super 304, Mg-ZrO, Mo-ODS, W, Ag & \multirow{2}{*}{3.3} \\
\hline & Tensile & HT-UPS-AX-6, NF709 & \\
\hline
\end{tabular}


Table 4. UW Experiment Rodlet List

\begin{tabular}{|l|c|c|l|c|}
\hline $\begin{array}{c}\text { Rodlet } \\
\text { Designation }\end{array}$ & $\begin{array}{c}\text { Design } \\
\text { Temperature } \\
\left({ }^{\circ} \mathbf{C}\right)\end{array}$ & $\begin{array}{c}\text { Nominal } \\
\text { Dose } \\
(\mathbf{d p a})\end{array}$ & Rodlet Contents & $\begin{array}{c}\text { Rodlet } \\
\text { Length } \\
(\mathbf{i n} .)\end{array}$ \\
\hline \hline 300 LO & 300 & 3 & TEM, Tensile & 4.4 \\
\hline 300 HI & 300 & 6 & TEM, Tensile & 3.9 \\
\hline 400 LO A & 400 & 3 & TEM & 2.4 \\
\hline 400 LO B & 400 & 3 & Tensile & 5.0 \\
\hline 400 HI A & 400 & 6 & TEM & 2.4 \\
\hline 400 HI B & 400 & 6 & Tensile & 6.3 \\
\hline 500 LO A & 500 & 3 & TEM & 3.1 \\
\hline 500 LO B & 500 & 3 & Tensile & 6.3 \\
\hline 500 HI A & 500 & 6 & TEM & 2.6 \\
\hline 500 HI B & 500 & 6 & Tensile & 6.3 \\
\hline 700 LO & 700 & 3 & TEM, Rod, Tensile & 3.8 \\
\hline 700 HI & 700 & 6 & TEM, Tensile & 3.3 \\
\hline
\end{tabular}

The UW irradiation test consists of four capsules, designated UW-0, UW-1, UW-2 and UW-3. Capsule UW-0 is an empty dummy capsule, capsules UW-1 and UW-2 contain the low-dose rodlets, and capsule UW-3 contains the high-dose rodlets. The initial configuration of the experiment consists of the UW-0, UW-1, and UW-3 capsules. After reaching approximately 3 dpa, the UW experiment will be reconfigured; the UW-1 capsule will be removed from the experiment and replaced with the UW-2 capsule. The UW-1 and UW-2 capsules will have identical outer dimensions and will not require any additional analysis. The UW experiment will continue irradiation until the UW-2 capsule reaches approximately 3 dpa and the UW-3 capsule reaches approximately 6 dpa exposure.

The maximum fast flux in the ATR East Flux Trap is approximately $9.7 \times 10^{13} \mathrm{n} / \mathrm{cm}^{2}-\mathrm{s}(\mathrm{E}>1 \mathrm{MeV})$. A dose of $1 \mathrm{dpa}$ in stainless steel is roughly equivalent to a fluence of $7 \times 10^{20} \mathrm{n} / \mathrm{cm}^{2}$. Using these values, material specimens near the core mid-plane will reach a dose of 3 dpa in approximately 250 Effective Full Power Days (EFPDs) and 6 dpa in approximately 500 EPFDs.

The experiment materials' compositions are listed in Table 5 through Table 9. 
Table 5. UW Experiment Material Composition $\dagger$ - Metallic Alloys

\begin{tabular}{|c|c|c|c|c|c|c|c|c|c|c|c|c|c|c|c|c|c|c|c|c|}
\hline $\begin{array}{l}\text { Material ID } \\
\text { \& Supplier } \\
\end{array}$ & $\begin{array}{l}\text { Density } \\
\left(\mathrm{g} / \mathrm{cm}^{3}\right) \\
\end{array}$ & B & C & $\mathbf{N}$ & $\mathbf{O}$ & Al & $\mathbf{S i}$ & $\mathbf{P}$ & $\mathbf{S}$ & $\mathbf{T i}$ & $\mathbf{V}$ & $\mathrm{Cr}$ & Mn & $\mathrm{Fe}$ & $\mathbf{N i}$ & $\mathrm{Cu}$ & Nb & Mo & $\mathbf{W}$ & Other \\
\hline $\begin{array}{l}\text { HT-9 } \\
\text { EBR-II }\end{array}$ & 7.7 & - & 0.22 & - & - & - & 0.39 & - & - & - & 0.22 & 11.92 & 0.76 & bal & 0.92 & - & - & 1.01 & 1.04 & \\
\hline $\begin{array}{l}\text { HT-9 } \\
\text { LANL }\end{array}$ & 7.7 & - & 0.171 & 0.031 & 0.013 & 0.007 & 0.41 & 0.007 & 0.004 & 0.002 & 0.34 & 12.1 & 0.61 & bal & 0.59 & 0.025 & - & 0.97 & 0.58 & Co: 0.009 \\
\hline $\begin{array}{l}\text { HT-9 } \\
\text { ORNL }\end{array}$ & 7.7 & - & 0.2 & 0.047 & - & $<0.01$ & 0.22 & 0.020 & 0.006 & $<0.01$ & 0.3 & 11.630 & 0.52 & bal & 0.500 & 0.04 & - & 1.00 & 0.52 & Co: 0.08 \\
\hline $\begin{array}{l}\text { T91 } \\
\text { INL } \\
\end{array}$ & 7.7 & - & 0.1 & 0.048 & - & 0.022 & 0.28 & 0.009 & 0.003 & - & 0.216 & 8.37 & 0.45 & bal & 0.21 & 0.17 & 0.076 & 0.90 & - & \\
\hline $\begin{array}{l}\text { HCM12A } \\
\text { JAEA }\end{array}$ & 7.7 & - & 0.09 & 0.0424 & - & - & 0.30 & 0.005 & - & - & & 10.50 & 0.52 & bal & 1.04 & 1.5 & - & 0.26 & 1.43 & $\begin{array}{c}\mathrm{Nb}+\mathrm{Ta}: \\
0.05\end{array}$ \\
\hline $\begin{array}{l}\text { HCM12A-TMP } \\
\text { JAEA }\end{array}$ & 7.7 & - & 0.09 & 0.0424 & - & - & 0.30 & 0.005 & - & - & & 10.50 & 0.52 & bal & 1.04 & 1.5 & - & 0.26 & 1.43 & $\begin{array}{c}\mathrm{Nb}+\mathrm{Ta}: \\
0.05\end{array}$ \\
\hline $\begin{array}{l}\text { NF616 } \\
\text { JAEA }\end{array}$ & 7.7 & 0.0017 & 0.109 & 0.0474 & 0.0042 & 0.005 & 0.102 & 0.012 & 0.0032 & - & 0.194 & 8.82 & 0.45 & bal & 0.174 & - & 0.064 & 0.468 & 1.87 & \\
\hline $\begin{array}{l}\text { 9Cr ODS } \\
\text { JAEA } \\
\end{array}$ & 7.7 & - & 0.14 & 0.017 & 0.14 & - & 0.048 & $<0.005$ & 0.003 & 0.23 & - & 8.60 & 0.05 & bal & 0.06 & - & - & - & 1.95 & \begin{tabular}{|c|} 
Y: 0.28 \\
Ar: 0.004 \\
\end{tabular} \\
\hline $\begin{array}{l}800 \mathrm{H} \\
\text { INL }\end{array}$ & 7.89 & - & 0.069 & - & - & 0.50 & 0.13 & 0.014 & 0.001 & 0.57 & - & 20.42 & 0.76 & bal & 31.59 & 0.42 & - & - & - & \\
\hline $\begin{array}{l}\text { 800H-TMP } \\
\text { INL } \\
\end{array}$ & 7.89 & - & 0.069 & - & - & 0.50 & 0.13 & 0.014 & 0.001 & 0.57 & - & 20.42 & 0.76 & bal & 31.59 & 0.42 & - & - & - & \\
\hline $\begin{array}{l}\text { 9Cr Model Alloy } \\
\text { Ames }\end{array}$ & 7.7 & - & 0.720 & - & - & - & - & - & - & - & - & 8.68 & - & bal & - & - & - & - & - & \\
\hline $\begin{array}{l}\text { 12Cr Model Alloy } \\
\text { Ames }\end{array}$ & 7.7 & - & 0.776 & - & - & - & - & - & - & - & - & 12.46 & - & bal & - & - & - & - & - & \\
\hline $\begin{array}{l}\text { HT-UPS-AX-6 } \\
\text { ORNL }\end{array}$ & 7.89 & 0.002 & 0.06 & 0.021 & 0.011 & 0.02 & 0.11 & 0.037 & 0.013 & 0.28 & 0.53 & 13.91 & 2.00 & bal & 16.00 & 0.02 & 0.11 & 2.59 & 0.02 & Co: 0.02 \\
\hline \begin{tabular}{|l|} 
D9 \\
EBR-II \\
\end{tabular} & 7.89 & - & - & - & - & 0.02 & - & - & - & - & 0.02 & 13.35 & 1.70 & bal & 16.27 & 0.01 & - & 1.55 & - & Co: 0.03 \\
\hline $\begin{array}{l}\text { NF709 } \\
\text { ORNL }\end{array}$ & 7.89 & 0.0047 & 0.078 & 0.102 & - & - & 0.47 & 0.016 & 0.0001 & - & - & 20.41 & 0.99 & bal & 26.0 & - & 0.34 & 1.50 & - & \\
\hline $\begin{array}{l}\text { Super 304H } \\
\text { ORNL }\end{array}$ & 7.89 & 0.002 & 0.08 & 0.107 & 0.012 & 0.01 & 0.24 & 0.018 & 0.004 & $<0.01$ & 0.06 & 19.13 & 0.47 & bal & 9.19 & 3.00 & 0.50 & 0.15 & 0.02 & Co: 0.11 \\
\hline
\end{tabular}

$\dagger$ Composition in weight percent 
Table 6. UW Experiment Material Composition $\dagger-$ Ceramics

\begin{tabular}{|l|c|c|c|}
\hline $\begin{array}{l}\text { Material ID } \\
\text { \& Supplier }\end{array}$ & $\begin{array}{c}\text { Density } \\
\left(\mathbf{g} / \mathbf{c m}^{\mathbf{3}}\right)\end{array}$ & $\mathbf{S i}$ & $\mathbf{C}$ \\
\hline \hline $\begin{array}{l}\mathrm{SiC} \\
\text { Novatech }\end{array}$ & 3.10 & 0.50 & 0.50 \\
\hline
\end{tabular}

Table 7. UW Experiment Material Composition $\dagger-$ Refractory Alloys and Silver

\begin{tabular}{|c|c|c|c|c|c|c|c|c|c|c|c|c|c|c|c|}
\hline $\begin{array}{l}\text { Material ID } \\
\text { \& Supplier }\end{array}$ & $\begin{array}{l}\text { Density } \\
\left(\mathrm{g} / \mathrm{cm}^{3}\right)\end{array}$ & C & $\mathbf{O}$ & Mg & Al & $\mathrm{Ca}$ & Ti & $\mathrm{Cr}$ & Mo & Sn & $\mathbf{P b}$ & $\mathbf{L a}$ & W & Ag & Other \\
\hline $\begin{array}{l}\text { Mo-ODS } \\
\text { H.C. Starck } \\
\end{array}$ & 10.28 & 0.005 & 0.2250 & 0.001 & 0.001 & 0.001 & 0.001 & 0.001 & 98.500 & 0.001 & 0.001 & 1.07 & - & - & \\
\hline $\begin{array}{l}\text { W } \\
\text { Westinghouse }\end{array}$ & 19.25 & - & - & - & - & - & - & - & - & - & - & - & 99.95 & - & \\
\hline $\begin{array}{l}\mathrm{Ag} \\
\text { Westinghouse }\end{array}$ & 10.5 & - & - & - & - & - & - & - & - & - & - & - & - & 99.95 & \\
\hline
\end{tabular}

$\dagger$ Composition in weight percent

Table 8. UW Experiment Material Composition $\dagger$ - Amorphous Metals Fabricated at UW

\begin{tabular}{|c|c|c|c|c|c|c|c|c|c|c|c|c|c|c|c|}
\hline Material ID & \begin{tabular}{|l|l|} 
Density \\
$\left(\mathrm{g} / \mathrm{cm}^{3}\right)$
\end{tabular} & $\mathbf{F e}$ & $\mathrm{Cr}$ & Mn & Mo & $\mathbf{W}$ & $\mathbf{Z r}$ & Nb & $\mathbf{Y}$ & $\mathbf{N i}$ & $\mathbf{T i}$ & $\mathbf{V}$ & B & $\mathbf{C}$ & $\mathbf{S i}$ \\
\hline Amorphous Fe-B 1 & 7.4 & 54.40 & 18.45 & 2.05 & 13.91 & 5.76 & - & - & - & - & - & - & 3.22 & 0.89 & 1.32 \\
\hline Amorphous Fe-B 2 & 7.4 & 54.65 & 18.53 & 2.05 & 4.53 & 5.79 & 8.98 & - & - & - & - & - & 3.24 & 0.90 & 1.33 \\
\hline Amorphous Fe-B 3 & 7.4 & 58.57 & 19.71 & 2.15 & 4.74 & 6.06 & - & - & - & - & 2.96 & - & 3.45 & 0.97 & 1.39 \\
\hline Amorphous Fe-B 4 & 7.4 & 56.41 & 19.17 & 2.13 & 4.69 & 5.99 & - & - & - & 5.98 & - & - & 3.35 & 0.93 & 1.37 \\
\hline Amorphous Fe-B 5 & 7.4 & 76.53 & 1.59 & - & - & - & 3.73 & 3.79 & 5.27 & - & - & 4.68 & 4.41 & - & - \\
\hline
\end{tabular}

$\dagger$ Composition in weight percent

Table 9. UW Experiment Material Composition $\dagger-\mathrm{MgO}-\mathrm{ZrO}_{2}$ Fabricated at UW

\begin{tabular}{|c|c|c|c|c|}
\hline Material ID & $\begin{array}{l}\text { Density } \\
\left(\mathrm{g} / \mathrm{cm}^{3}\right)\end{array}$ & $\mathbf{M g}$ & $\mathbf{Z r}$ & o \\
\hline $\mathrm{MgO}-\mathrm{ZrO}_{2}$ & 44.15 & 424.1 & 22.2 & 35.5 \\
\hline
\end{tabular}

$\dagger$ Composition in weight percent 


\section{TEST DESCRIPTION}

\subsection{Material Specimens}

Three sample geometries will be included in the UW irradiation experiment:

- TEM specimens are 0.118 in. $(3 \mathrm{~mm})$ diameter disks, 0.008 in $(0.2 \mathrm{~mm})$ thick. Where TEM specimens are identified, 4 TEM disks of each material will be included.

- $\mathrm{SiC}$ rod specimens are 0.1845 in. $(4.7 \mathrm{~mm})$ diameter cylinders, 0.5 in. $(12.7 \mathrm{~mm})$ tall.

- Tensile specimens are 0.157 in. $(4 \mathrm{~mm})$ wide, 0.63 in. $(16 \mathrm{~mm})$ long, and 0.039 in. $(1 \mathrm{~mm})$ thick. Where tensile specimens are identified, 2 tensile specimens of each material will be included.

Schematics of the sample geometries are shown in Figure 1, Figure 2, and Figure 3. The material specimens will be contained in a stainless steel fixture or foil wrap in order to keep the samples aligned in a vertical stack inside the rodlets. SiC strips may be used next to select tensile specimens as temperature monitors to be processed via postirradiation emissivity testing. SiC temperature monitors are 0.039 in. (1 $\mathrm{mm})$ wide, up to 0.63 in. $(16 \mathrm{~mm})$ long, and $0.030 \mathrm{in} .(0.75 \mathrm{~mm})$ thick.

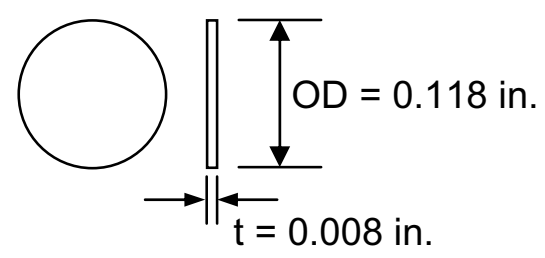

Figure 1. TEM Specimen Schematic

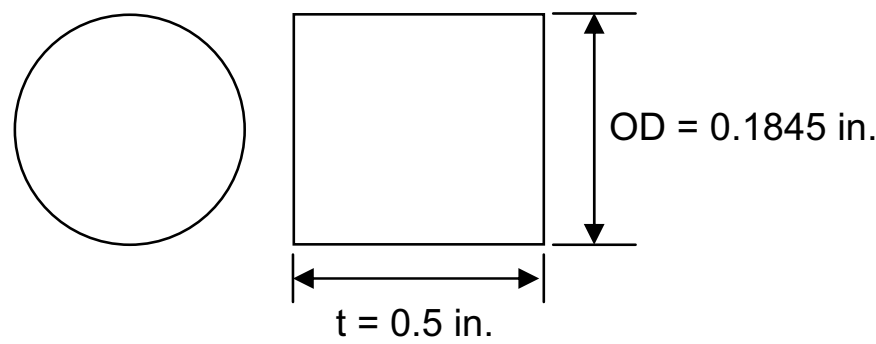

Figure 2. SiC Rod Specimen Schematic 


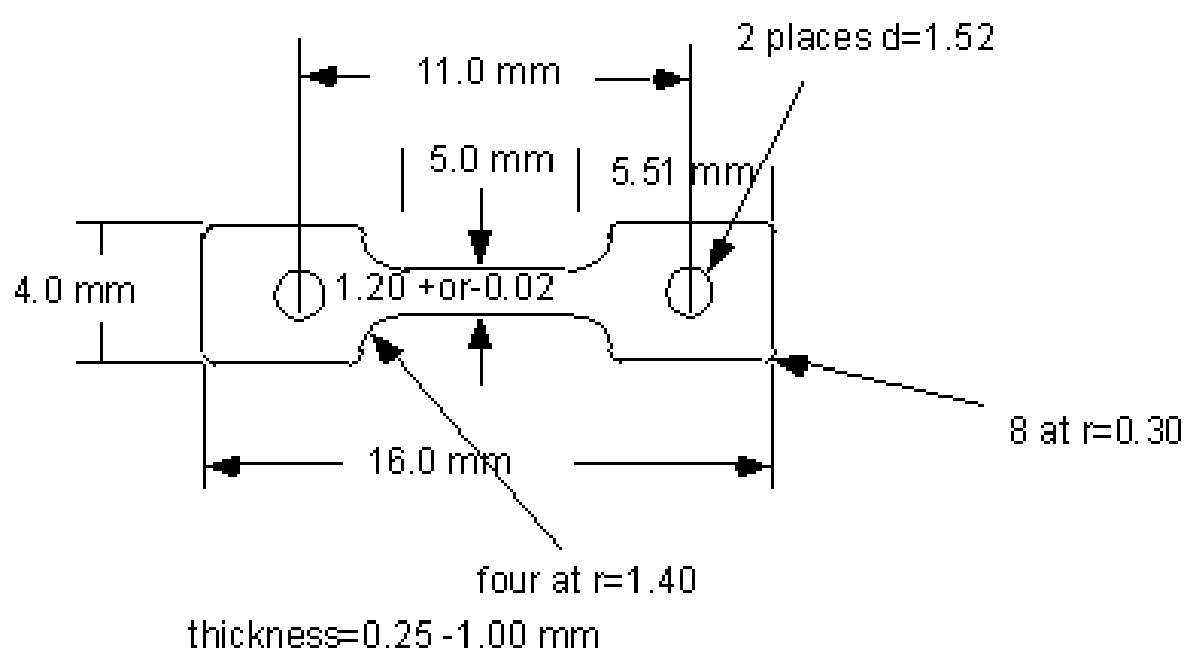

Figure 3. Tensile Specimen Schematic

\subsection{Rodlet Assembly}

The rodlet assemblies follow the design of the fuel rodlet for the AFC test series. Rodlet assemblies consist of the material specimens, an inert gas fill, and a stainless steel Type 421 (HT-9) cladding. Table 10 shows the materials used in constructing the rodlets along with their radial design dimensions.

Table 10. Rodlet Assembly Design Data

\begin{tabular}{|l|c|}
\hline Design Parameter & Value \\
\hline \hline Cladding Material & 421SS (HT9) \\
\hline Cladding O.D. & 0.230 in. \\
\hline Cladding I.D. & 0.194 in. \\
\hline Gas Fill & Helium/Argon* \\
\hline
\end{tabular}

* The helium/argon mixture will be adjusted during experiment fabrication to achieve desired irradiation temperatures.

The rodlet assembly consists of the material column, helium and/or argon fill gas, and stainless steel Type 421 (HT-9) cladding. A stainless steel capsule assembly will contain a vertical stack of rodlet assemblies. The material specimens and rodlet and capsule radial dimensions are shown in Figure 4 and Figure 5. The gap between the material specimens column and rodlet inner diameter is filled by a gas mixture of helium and/or argon (determined for each rodlet) designed to provide the thermal resistance necessary to achieve the design irradiation temperature of the material specimens. The annular helium-filled gap between the rodlet outer diameter and capsule inner diameter is designed to provide additional thermal resistance necessary to achieve the design irradiation temperature of the material specimens. 


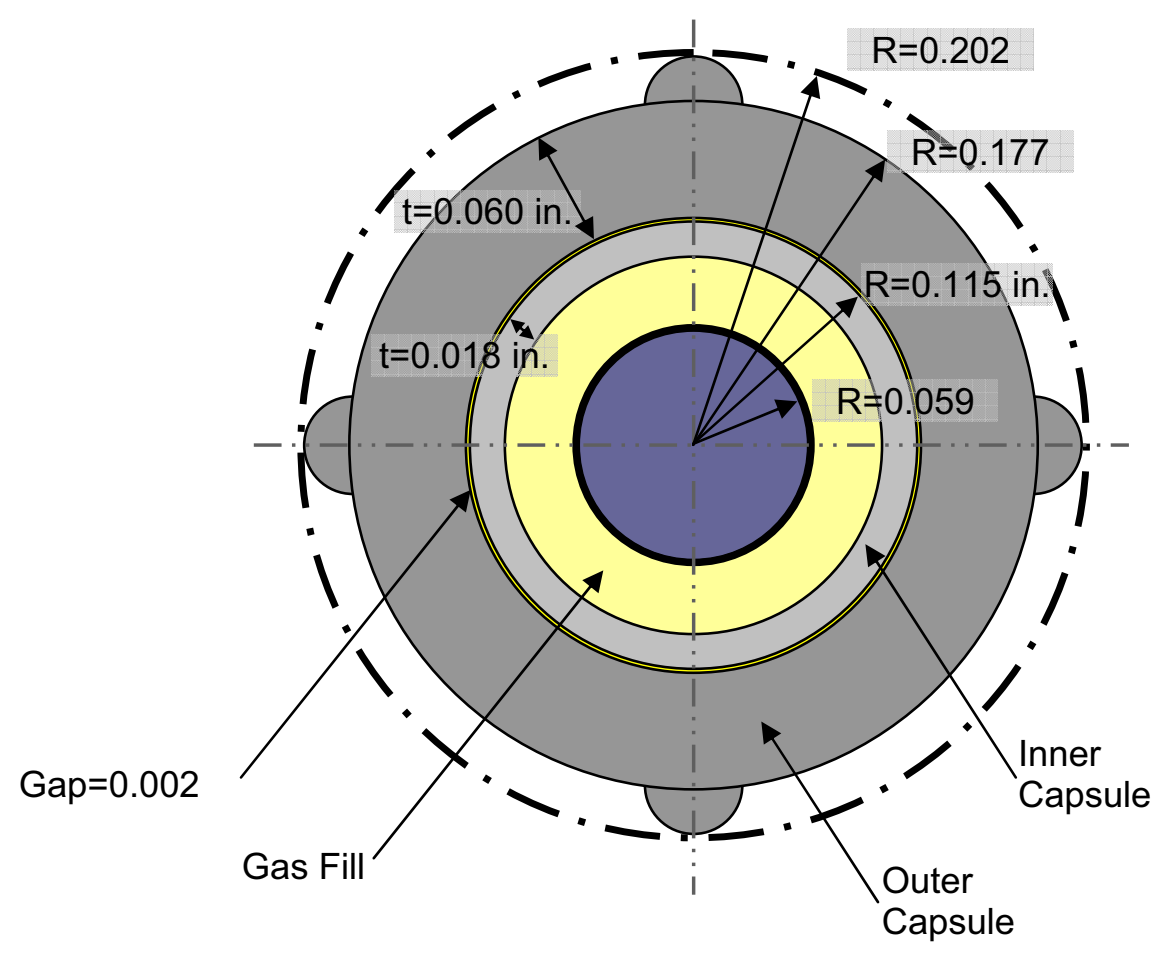

Figure 4. Radial dimensions of rodlet and capsule assemblies for the UW materials irradiation - TEM specimens

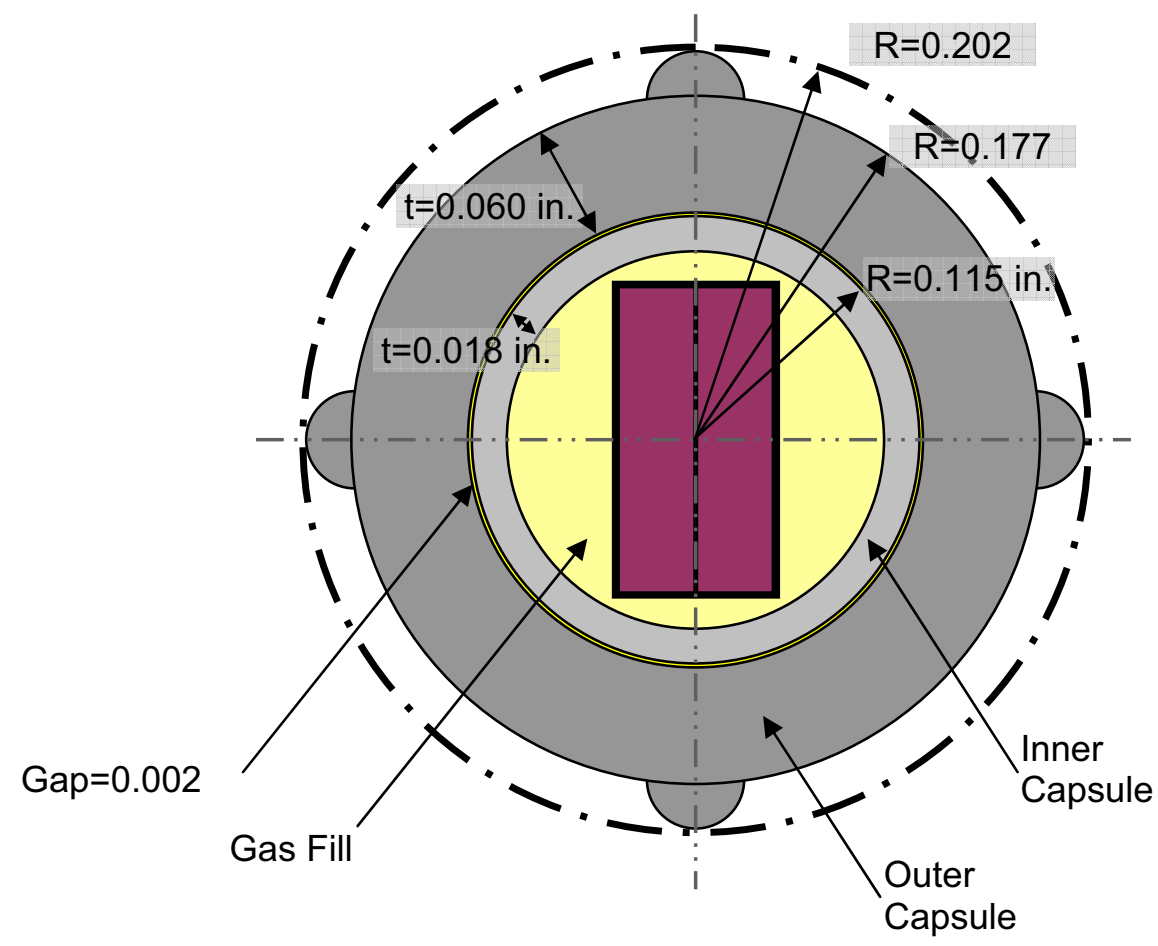

Figure 5. Radial dimensions of rodlet and capsule assemblies for the UW materials irradiation - tensile specimens 
Figure 6 shows the rodlet assembly axial dimensions. The design length of the total material specimens stack varies between 0.598 in. and 3.780 in.; the material specimens stack will consist of TEM disks, rods, and/or tensile specimens. Insulator disks may be used at the top and/or bottom of the material specimens stack to provide thermal insulation to achieve desired design irradiation temperatures. The cladding length for the rodlet assemblies varies between $2.40 \mathrm{in.} \mathrm{and} 6.30 \mathrm{in}$. (including welded endplugs) with 0.230 -in. outer diameter and 0.194-in. inner diameter. The rodlets will be filled with helium and/or argon to provide the necessary thermal conductivity to achieve desired design irradiation temperatures.
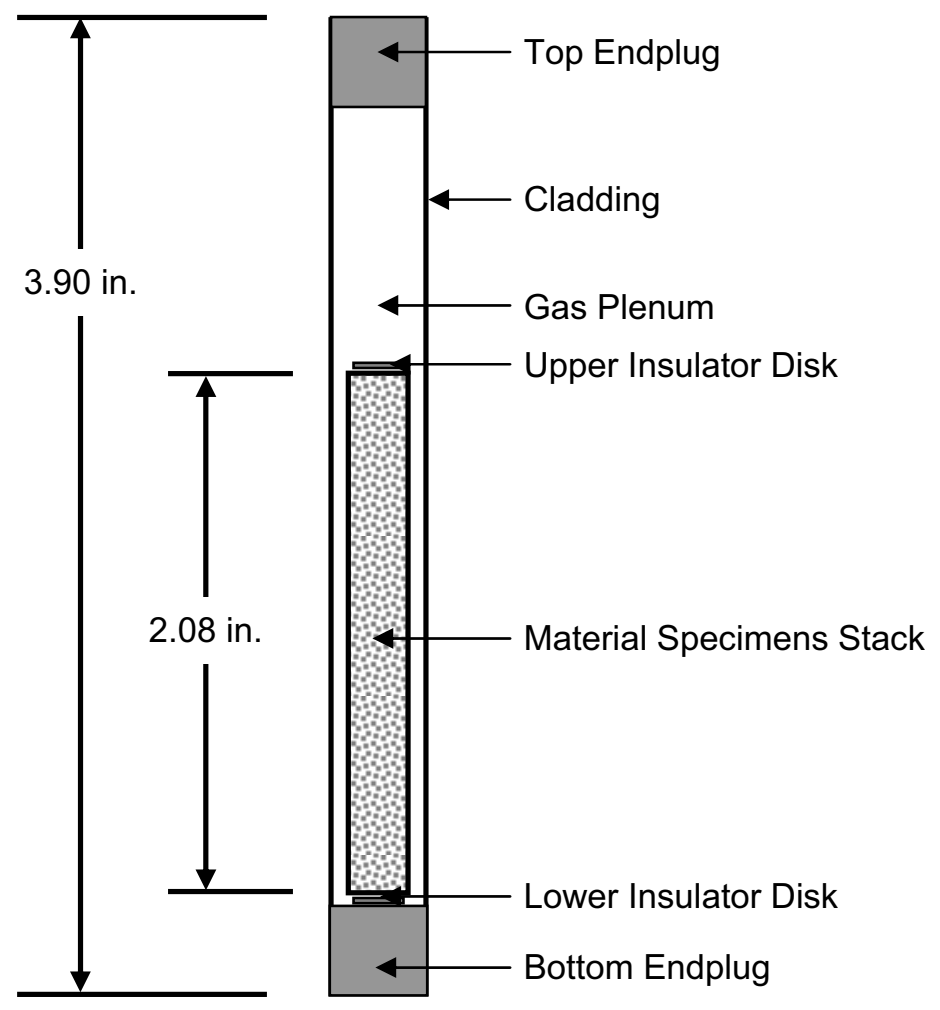

Figure 6. Example rodlet axial configuration for the UW irradiation experiment

\subsection{Capsule Assembly}

The capsule assembly function is to provide a second, robust barrier between the water coolant and the materials specimens. The relevant design data for the capsule assembly is summarized in Table 11. The capsule assembly will be fabricated to meet the intent of the ASME, Section III, Class 1 pressure vessel code requirements. The capsule assembly design will be identical for all UW capsules, except for the overall length. 
Table 11. Capsule Assembly Design Data

\begin{tabular}{|l|c|}
\hline Design Parameter & Value \\
\hline \hline Capsule Material & $316 \mathrm{SS}$ \\
\hline Capsule O.D. & 0.354 in. \\
\hline Capsule I.D. & 0.234 in. \\
\hline Gas Fill & Helium/Argon* \\
\hline Capsule - Rodlet Gap & 0.0022 in. \\
\hline
\end{tabular}

* The helium/argon mixture will be adjusted during experiment fabrication to achieve desired irradiation temperatures.

A total of four capsule assemblies will be used for the UW experiment, as listed in Table 12. Two lowdose capsules and one high-dose capsule will contain the materials specimens and one empty dummy capsule will fill the remaining required vertical space so that the overall capsule stack matches the AFC-1 and AFC-2 series capsule. The two low-dose capsules will have the same outer dimensions and will be exchanged after approximately half of the irradiation duration so that they both attain approximately 3 dpa while the high-dose capsule attains 6 dpa. A schematic of the capsule configuration and the proposed loading of the capsules is shown in Figure 7.

Table 12. Capsule Assembly List

\begin{tabular}{|l|c|c|}
\hline \multicolumn{1}{|c|}{ Capsule ID } & Description & Height (in.) \\
\hline Dummy & Empty Capsule & 15.75 \\
\hline UW-1, UW-2 & Low Dose & 16.6 \\
\hline UW-3 & High Dose & 27.4 \\
\hline
\end{tabular}




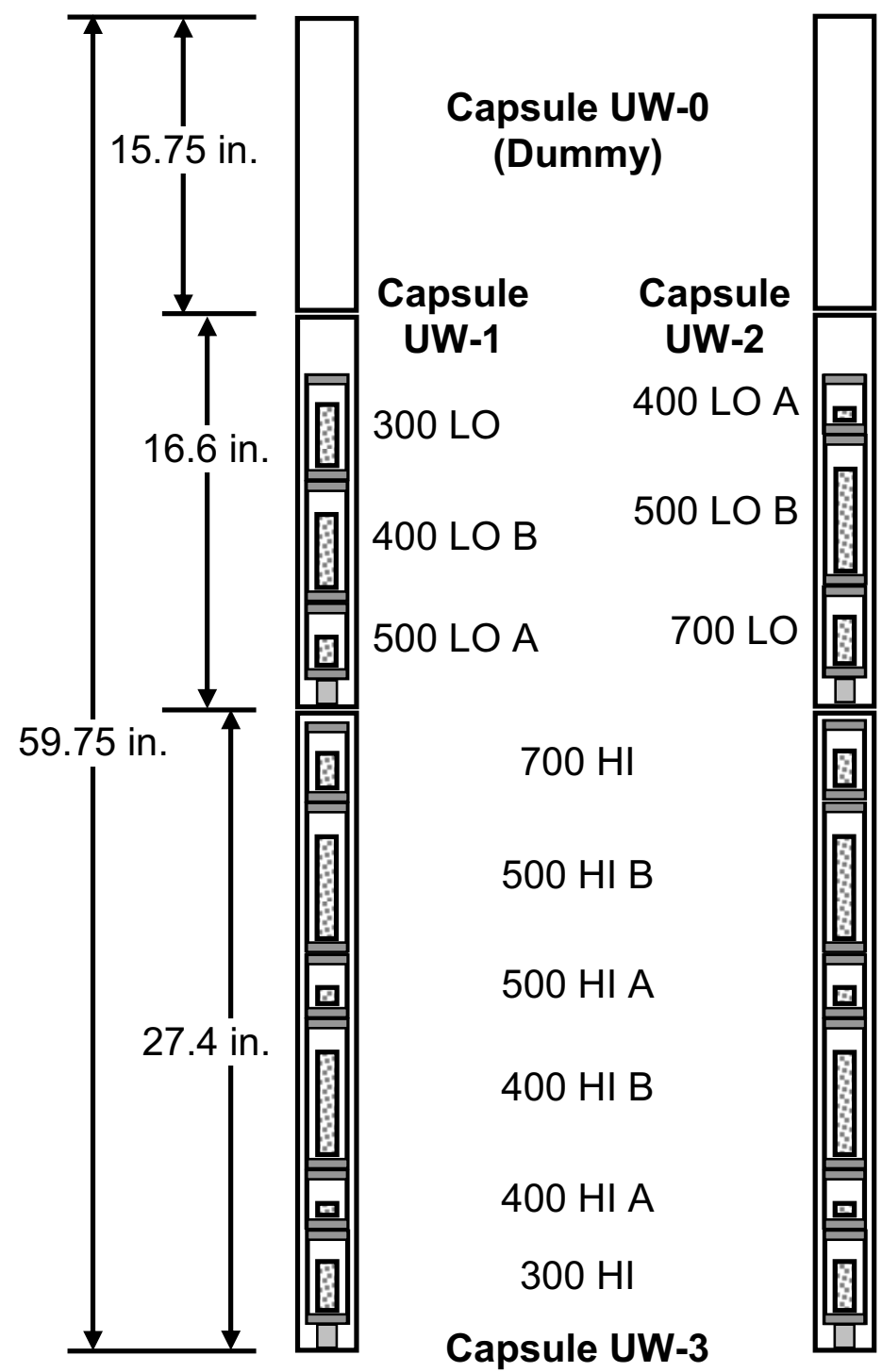

Figure 7. Capsule Assembly Schematic with Proposed Rodlet Loading

\subsection{Irradiation Test Assembly}

The irradiation test assembly, capsule assembly, and rodlet assembly are shown in Figure 8. The irradiation test assembly consists of the experiment basket and capsule assembly, which contains three vertically-stacked capsules. The capsule assemblies contain up to six vertically-stacked rodlet assemblies. The experiment basket of the test assembly is an aluminum-sheathed cadmium tube designed to interface the capsule assembly with the ATR and to act as a thermal neutron flux filter. The aluminum sheath accommodates a cadmium tube thickness between $0.021 \mathrm{in}$. and $0.045 \mathrm{in}$. For the UW experiment, it is proposed that the cadmium thickness be the same as in the AFC-1 and AFC-2 experiments design, which is $0.045 \mathrm{in}$. 
The overall UW capsule assembly will be 59.75-in. tall and will not utilize a basket spacer. The overall UW capsule assembly will have the same height as the AFC-1 and AFC-2 series capsules which employ a 52-in. tall capsule assembly (drawing 747159) with a 7.75-in. tall basket spacer (drawing 520140 Rev. 4, Item 1). The hardware interfaces between the experiment basket, capsule assembly, and rodlet assembly are the same in the UW test as in the AFC-1 and AFC-2 test series. All radial dimensions and cooling channel widths are also the same. All rodlets and capsules will be fabricated using the same materials and dimensions as the AFC-1 and AFC-2 rodlets and capsules, with the exception of length as designated in Table 3 and Table 12.

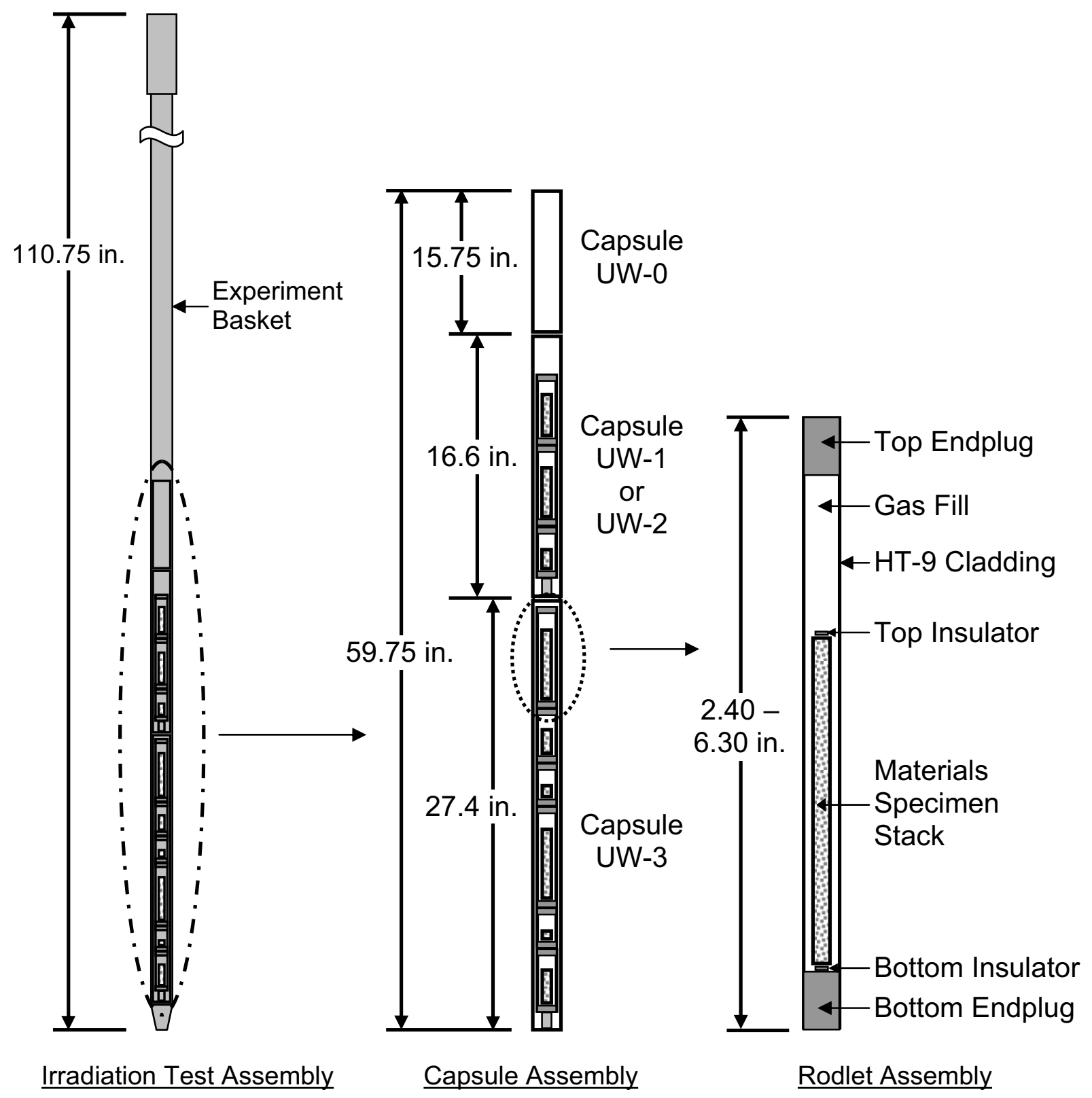

Figure 8. UW Experiment Irradiation Test Assembly for ATR East Flux Trap Positions 


\section{IRRADIATION EXPERIMENT CONDITIONS}

The UW experiment is designed for irradiation in the ATR East Flux Trap. The experiment will be inserted in an ATR East Flux Trap drop-in position that, together with the cadmium neutron filter basket, will achieve the design irradiation conditions.

The UW experiment design conditions are shown in Table 13. The design objective is for each rodlet to operate at its design temperature, as listed in Table 4, during irradiation. The internal heating for each rodlet will be calculated using the MCNP Coupled with ORIGEN2 (MCWO) analysis methodology. The nominal target doses are 3 dpa for the UW-1 and UW-2 capsules, and 6 dpa for the UW-3 capsule; the actual doses achieved by each capsule will vary depending on the ATR operating schedule. Capsule discharge will be based on actual and projected ATR operations and discussions between INL and UW.

Table 13. UW Experiment Design Conditions

\begin{tabular}{|c|c|c|}
\hline Performance Parameter & \multicolumn{2}{|c|}{ Value } \\
\hline \multirow{2}{*}{ Nominal Dose } & UW-1 \& UW-2 & UW-3 \\
\hline & $3 \mathrm{dpa}$ & $6 \mathrm{dpa}$ \\
\hline $\begin{array}{c}\text { Peak Cladding Temperature } \\
\text { - Off-Normal Limit }\end{array}$ & \multicolumn{2}{|c|}{$650^{\circ} \mathrm{C}$} \\
\hline Nominal Specimen Temperature & \multicolumn{2}{|c|}{$300-700^{\circ} \mathrm{C}$} \\
\hline
\end{tabular}

The peak rodlet cladding temperature should not exceed $650^{\circ} \mathrm{C}$ during off-normal conditions. The expected peak thermal conditions during irradiation for these experiments will be estimated based on thermal analysis using sample heating rates calculated by MCWO.

\section{POSTIRRADIATION SERVICES}

Upon discharge of each experiment from the reactor, cooling in the ATR canal will be required. The cooling period is typically 30 days; however, calculations will be performed to determine the total projected activity and radiation levels to ensure compliance with Department of Transportation regulations. The capsule assembly and aluminum sheathed cadmium segment of the basket assembly will be shipped to the Hot Fuels Examination Facility (HFEF) at the Materials and Fuels Complex (MFC) for postirradiation examinations. Shipment from the Reactor Technology Complex (RTC) to HFEF at MFC will be made using the GE Model 2000 shipping cask or other authorized shipping container. After the capsule assemblies and cadmium bearing segments of the basket assemblies are loaded in the cask, the remnants of the basket assemblies should be considered scrap. Postirradiation examination is further described in the Program Execution Plan (INL PLN-2765).

\section{PROPOSED SCHEDULE}

The schedule shown below is proposed to meet the required deadlines prior to insertion of the UW irradiation experiment into ATR for irradiation beginning in September 2008. In the event the primary test cannot be inserted during the scheduled reactor outage, a backup test will be ready and available to insert into the ATR EFT to support reactor startup. 
$\underline{\text { Deliverable }}$

$\underline{\text { Date }}$

Fabrication As-Built Data Package ......................................August 11, 2008

Experiment Safety Assurance Package (ESAP).....................August 14, 2008

UW-1, UW-2, and UW-3 Irradiation Test Assemblies ...........August 18, 2008

\section{RESPONSIBILITIES}

University of Wisconsin is responsible for the fabrication of the specimen materials and will deliver the test specimens to Idaho National Laboratory. Idaho National Laboratory will fabricate the experiments and deliver the irradiation test assemblies to ATR. Heather MacLean has overall responsibility for these irradiation experiments and is responsible for experiment design and postirradiation examinations. Debbie Utterbeck is responsible for irradiation planning activities and transportation. Timothy Hyde is responsible for experiment fabrication. Julie Foster is responsible for coordination and facilitation of lifecycle project activities to support the objective of the experiment, ensuring that the experiment in completed within baseline constraints of the project, managing project team members to ensure task completion, and any change management activities required during the lifecycle of the project. 